\title{
SPATIAL VARIABILITY OF THE RAINFALL EROSIVE POTENTIAL IN THE STATE OF MATO GROSSO DO SUL, BRAZIL
}

\section{PAULO T. S. OLIVEIRA ${ }^{1}$, DULCE B. B. RODRIGUES ${ }^{2}$, TEODORICO A. SOBRINHO ${ }^{3}$, DANIEL F. DE CARVALHO ${ }^{4}$, ELÓI PANACHUKI ${ }^{5}$}

\begin{abstract}
Information about rainfall erosivity is important during soil and water conservation planning. Thus, the spatial variability of rainfall erosivity of the state Mato Grosso do Sul was analyzed using ordinary kriging interpolation. For this, three pluviograph stations were used to obtain the regression equations between the erosivity index and the rainfall coefficient $\mathrm{EI}_{30}$. The equations obtained were applied to 109 pluviometric stations, resulting in $\mathrm{EI}_{30}$ values. These values were analyzed from geostatistical technique, which can be divided into: descriptive statistics, adjust to semivariogram, cross-validation process and implementation of ordinary kriging to generate the erosivity map.Highest erosivity values were found in central and northeast regions of the State, while the lowest values were observed in the southern region. In addition, high annual precipitation values not necessarily produce higher erosivity values.
\end{abstract}

KEYWORDS: water erosion, rainfall erosivity index, geostatistics.

\section{VARIABILIDADE ESPACIAL DO POTENCIAL EROSIVO DAS CHUVAS NO ESTADO DE MATO GROSSO DO SUL}

RESUMO: Informações sobre erosividade das chuvassão importantes no planejamento conservacionista do solo e da água. Assim, analisou-se a variabilidade espacial da erosividade das chuvas no Estado de Mato Grosso do Sul,a partir de interpolação por krigagem ordinária. Para tanto, foram utilizadas três estações pluviográficas para obtenção de equações de regressão entre o índice de erosividade $\mathrm{EI}_{30}$ e o coeficiente de chuvas. As equações obtidas foram aplicadas a 109 estações pluviométricas, obtendo-se, assim, os valoresEI $\mathrm{I}_{30}$. Esses valores foram analisados, utilizando-se da técnica de geoestatística, podendo ser dividida em: estatística descritiva; ajuste ao semivariograma; processo de validação cruzada e aplicação da krigagem ordinária para a geração do mapa de valores de erosividade. Verificou-se que os maiores valores de erosividade se encontraram nas regiões central e nordeste do Estado, enquanto os menores valores são observados na região sul. Além disso, valores elevados de precipitação anual não necessariamente produzem maiores valoresdeerosividade.

PALAVRAS-CHAVE: erosão hídrica, índice de erosividade, geoestatística.

\footnotetext{
${ }^{1}$ Eng $^{\mathrm{o}}$ Ambiental, Doutorando em Engenharia Hidráulica e Saneamento, Universidade de São Paulo, USP, São Carlos - SP, paulot@sc.usp.br.

${ }^{2}$ Eng ${ }^{\circ}$ Ambiental, Doutoranda em Engenharia Hidráulica e Saneamento, Universidade de São Paulo, USP, dulce@ sc.usp.br.

${ }^{3}$ Eng $^{\text {o }}$ Agrônomo, Professor Associado III, Universidade Federal de Mato Grosso do Sul, CCET/UFMS, Campo Grande - MS, teodorico.alves@ufms.br. Bolsista do CNPq.

${ }^{4}$ Eng $^{\circ}$ Agrícola, UFRRJ, Instituto de Tecnologia, Departamento de Engenharia, Seropédica - RJ, carvalho@ufrrj.br. Bolsista do CNPq.

${ }^{5}$ Eng ${ }^{\mathrm{O}}$ Agrônomo, Professor da Universidade Estadual de Mato Grosso do Sul, UEMS, Aquidauana - MS, eloip@uems.br.

Recebido pelo Conselho Editorial em: 16-5-2010

Aprovado pelo Conselho Editorial em: 5-9-2011
} 


\section{INTRODUCTION}

Rainfall erosivity is considered one of the most important factors to estimate soil losses (SHAMSHAD et al., 2008). Intense precipitation events are responsible for most of soil erosion and sediment transport (GOOVAERTS, 1999). Thus, obtaining the value of rainfall erosivity is essential to assess the risk of soil erosion and to support conservation planning of soil and water.

Several studies using natural and artificial rain have been conducted to determine the effect of distribution and size of the raindrop on the detachment of soil particles. However, these parameters are of difficult measurement and the data used are spatially and temporally reduced. This has stimulated the development of studies related to rainfall, such as the maximum intensity over a period of time, total energy of the rain, or rate of direct breakdown of the soil (ANGULOMARTÍNEZ \& BEGUERÍA, 2009). As an example of erosivity index, it can be cited the R factor of Universal Soil Loss Equation (USLE), which summarizes all erosive events quantified by the $\mathrm{EI}_{30}$ index occurred over the year (WISCHMEIER \& SMITH, 1978), and the index KE $>25$, initially developed for South Africa (HUDSON, 1973) and that has been used in countries with tropical and subtropical climates (CARVALHO et al., 2010).

The $\mathrm{EI}_{30}$ index has been most widely used (HOYOS et al., 2005) with good correlation with soil loss in several studies (BERTOL et al., 2007; BERTOL et al., 2008, SILVA et al., 2009; CARVALHO et al., 2009). However, to obtain this factor a series of more than 20 years of rainfall records is recommended, which is not available for many regions of the world (HOYOS et al., 2005; CAPOLONGO et al., 2008). In this regard, in order to facilitate obtaining the R factor, models that associate the erosivity index of rainfall data (e.g., monthly, total annual rainfall and modified Fournier index) were proposed. These daily precipitation records are usually available for most locations with good spatial and temporal coverage, allowing the erosivity index to be obtained with sufficient accuracy in regions with no rainfall data (SILVA, 2004; ANGULO-MARTÍNEZ \& BEGUERÍA, 2009).

From estimates of discrete points, erosivity maps can be obtained by interpolation methods that use sampled values to estimate values in locations with restricted information or lack of precipitation (MONTEBELLER et al., 2007). By the end of the 80's decade, interpolation techniques, such as the inverse of distance, Thiessen polygons or isohyetal were used to interpolate rainfall data. Since the 90's, the interpolation method using geostatistical technique based on the theory of regionalized variables has been widely used (GOOVAERTS, 1999), because it allows the estimation at non-sampled data without bias and with minimum variance (MONTEBELLER et al., 2007).

CARVALHO \& ASSAD (2005) studied different rainfall interpolation methods in the State of São Paulo and concluded that ordinary kriging geostatistical interpolation showed the best results in comparison with other methods that ignore the spatial dependence between observations. Thus, studies were performed using kriging interpolation to obtain erosivity maps, such as the study by SHAMSHAD et al. (2008) in Peninsular Malaysia, ANGULO-MARTÍNEZ et al. (2009) in northeastern Spain, ZHANG et al. (2010) in northeast China, VIEIRA \& LOMBARDI NETO (1995) in the State of São Paulo, Brazil, MELLO et al. (2007) in the State of Minas Gerais, and MONTEBELLER et al. (2007) in the State of Rio de Janeiro.

In the State of Mato Grosso do Sul, as in many other Brazilian states, the lack of rainfall data makes it difficult to obtain more information on rainfall erosivity, which is an important hydrological index in the study and conservation of soil and water. Thus, this study analyzed the spatial variability of rainfall erosivity in the State of Mato Grosso do Sul, by using interpolation by ordinary kriging. 


\section{MATERIAL AND METHODS}

\section{Database}

This study was conducted for the State of Mato Grosso do Sul, located south of the centralwestern region of Brazil, with a total area of $358,158.7 \mathrm{~km}^{2}$. The data used to obtain the erosivity index were originated from three pluviometric stations located in the municipalities of Campo Grande, Dourados and Coxim, from the Universidade Anhanguera-Uniderp, Universidade Federal da Grande Dourados (UFGD) and from the Universidade Federal de Mato Grosso do Sul (UFMS) respectively. In addition to the information obtained from rainfall, data from 109 pluviometric stations, obtained from the Sistema de Informações Hidrológicas da Agência Nacional de Águas (HidroWeb) were also used in the study (Figure 1).

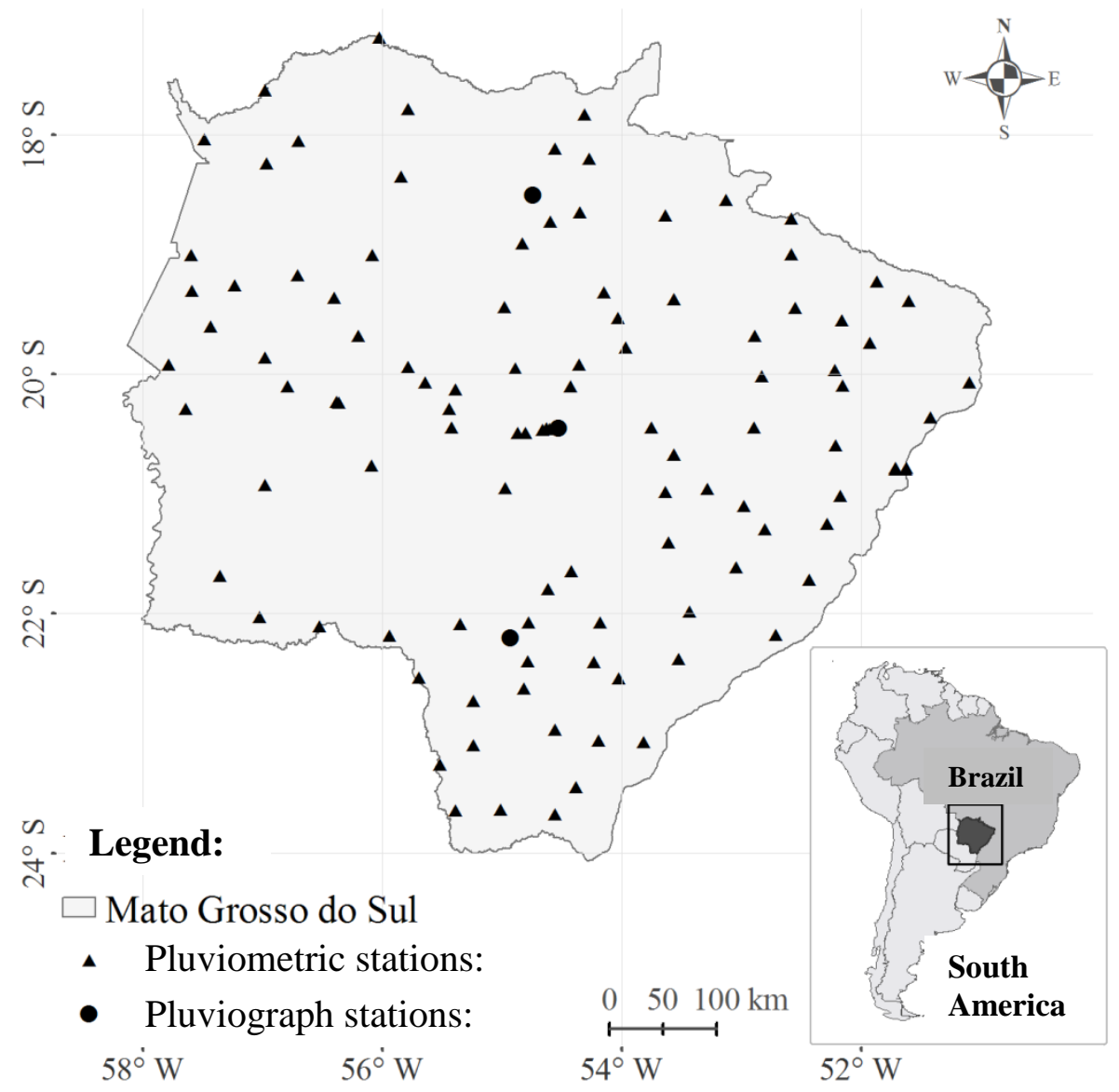

FIGURE 1. Pluviograph and pluviometric stations located in the state of Mato Grosso do Sul.

In Table 1 are presented information on the data series used in this study.

TABLE 1. Data series analyzed.

\begin{tabular}{cc}
\hline Stations & Years Analyzed \\
\hline Dourados & 8 \\
Coxim & 4 \\
Campo Grande & 3 \\
Agência Nacional de Águas (ANA) & Higher than 15 \\
\hline
\end{tabular}

Despite the fact that the historical series present periods of less than 20 years, the least amount of time considered suitable for estimating the average annual soil loss by USLE, it is worth to remember that in Brazil historical rainfall data series available are generally rare, and often they are 
not available (MONTEBELLER et al., 2007). Thus, several studies on this subject have been carried out with data series with less than the recommended periods (CARVALHO et al., 2005; MONTEBELLER et al., 2007; MACHADO et al., 2008; OLIVEIRA et al., 2009).

\section{Erosivity index}

For data obtained with pluviographs, the $\mathrm{EI}_{30}$ erosivity index was determined for each individual rainfall and for those classified as erosive rain. It was considered individual rainfall the one that is separated from the previous and the later for a minimum of 6 hours without rain or less than $1.0 \mathrm{~mm}$ in this period, and as erosive rain that with blade greater than $10.0 \mathrm{~mm}$ or with blade greater than or equal to $6.0 \mathrm{~mm}$ in a period of less than 15 minutes (WISCHMEIER, 1959). Individual and erosive rainfalls were processed in Chuveros software (CASSOL et al., 2008), allowing the estimation of monthly, annual and mean rainfall erosivity (WISCHMEIER, 1959). For each rain segment, the kinetic energy unit was determined according to eq.(1) (WISCHMEIER \& SMITH, 1978).

$$
\mathrm{e}=0.119+0.0873 \log _{10} \mathrm{i}
$$

where,

e - kinetic energy unit, $\mathrm{MJ} \mathrm{ha}^{-1} \mathrm{~mm}^{-1}$, and

$\mathrm{i}$ - intensity of the rain segment, $\mathrm{mm} \mathrm{h}^{-1}$.

The value obtained in eq.(1) was multiplied by the amount of rain in the respective uniform segment, to express its kinetic energy, in $\mathrm{MJ} \mathrm{ha}^{-1}$. In addition to the kinetic energy of all segments of uniform rain, it was obtained the total kinetic energy of rain $\left(\mathrm{Ec}_{\mathrm{t}}\right)$ (CASSOL et al., 2007). The $\mathrm{EI}_{30}$ was defined as the product of the maximum intensity of rainfall in 30 minutes $\left(\mathrm{I}_{30}\right)$ and $\mathrm{Ec}_{\mathrm{t}}$ (eq.(2)).

$$
\mathrm{EI}_{30}=\mathrm{Ec}_{\mathrm{t}} \mathrm{I}_{30}
$$

where,

$\mathrm{EI}_{30}$ - index of rainfall erosivity, $\mathrm{MJ} \mathrm{mm} \mathrm{ha}^{-1} \mathrm{~h}^{-1}$;

$\mathrm{Ec}_{\mathrm{t}}$ - total kinetic energy of rainfall, $\mathrm{MJ} \mathrm{ha}^{-1}$, and

$\mathrm{I}_{30}$ - maximum intensity of rain in 30 minutes, $\mathrm{mm} \mathrm{h}^{-1}$.

By addition of $\mathrm{EI}_{30}$ indices of all individual and erosive rainfall of each month, it was obtained the monthly rainfall erosivity and from the sum of monthly values, it was obtained the annual erosivity, which the average value was used in the USLER-factor.

From the $\mathrm{EI}_{30}$ values calculated for each rainfall station, regression analysis was carried out using linear and power models, and the rainfall coefficient (eq.(3)) (LOMBARDI NETO, 1977) as the independent variable.

$$
\mathrm{Rc}=\mathrm{p}^{2} \mathrm{P}^{-1}
$$

where,

Rc - rainfall coefficient, $\mathrm{mm}$;

$\mathrm{p}$ - average monthly rainfall, $\mathrm{mm}$, and

$\mathrm{P}$ - annual rainfall, $\mathrm{mm}$.

Power regression equations were applied using data from 109 rainfall stations available in the State of Mato Grosso do Sul, considering distance, altitude and rainfall as criteria for use of agiven regression equation, according to GONÇALVES et al. (2006) and MONTEBELLER et al. (2007).

After calculating the erosivity for each location, the erosivity map for the state was obtained through the interpolation process, using estimated values in places with no rain information. In this study, it was used the interpolation process by ordinary kriging, which has been applied in several 
Brazilian states to obtain erosivity (VIEIRA \& LOMBARDI NETO, 1995; MONTEBELLER et al., 2007; MELLO et al., 2007).

\section{Geostatistical analysis}

Erosivity values were first analyzed by descriptive statistics: mean, median, standard deviation, variance, coefficient of variation, coefficient of skewness, and kurtosis. The hypothesis of normality of the data series was verified using the Kolmogorov-Smirnov test with the BioEstat 5.0 (AYRES et al., 2007). The spatial dependence between the values of rainfall erosivity was assessed using the estimator of the semivariance function, usually called the classical estimator $\gamma(\mathrm{h})$, according to eq.(4).

$$
\gamma(\mathrm{h})=\frac{1}{2 \mathrm{~N}(\mathrm{~h})} \sum_{\mathrm{i}=1}^{\mathrm{N}(\mathrm{h})}\left[\mathrm{Z}\left(\mathrm{x}_{\mathrm{i}}\right)-\mathrm{Z}\left(\mathrm{x}_{\mathrm{i}}+\mathrm{h}\right)\right]^{2}
$$

where,

$\mathrm{N}(\mathrm{h})$ - number of pairs of experimental observations $\mathrm{Z}(\mathrm{xi})$, and

$\mathrm{Z}(\mathrm{xi}+\mathrm{h})$ - separated by a distance $\mathrm{h}$, and $\mathrm{xi}$ is a spatial position of the variable $\mathrm{Z}$.

The experimental semivariogram is represented by the graph of $\gamma(\mathrm{h})$ as a function of $\mathrm{h}$. Thus, after it was obtained in the GS+ software (ROBERTSON, 1998), an adjustment from a theoretical model that best represented it was performed, having as variables the nugget effect (Co), structural semivariance $(\mathrm{C})$, baseline $(\mathrm{C}+\mathrm{Co})$ and scope $(\mathrm{a})$.

The degree of dependence reflects the structure of spatial continuity, since it is obtained by the relationship between the baseline and the baseline plus the nugget effect of the semivariogram. To verify the degree of spatial dependence, it was used the index of spatial dependence (ISD), proposed by ZIMBACK (2001). ISD varies from low $(<25 \%)$, moderate $(25-75 \%)$ and strong $(>75 \%)$. From the ISD and the model that best fitted the semivariogram, cross-validation and application of ordinary kriging were carried out in the GS+ software (ROBERTSON, 1998). The final map of erosivity was developed in ArcGis 9.2 (ESRI, 2006).

In order to statistically verify the trends of the geographical distribution of rainfall erosivity in the State of Mato Grosso do Sul, statistical correlations were performed by applying the Student's ttest at $5 \%$ probability, between the annual data of rainfall erosivity with latitude, longitude, and average annual rainfall.

\section{RESULTS AND DISCUSSION}

The regression equations obtained from the $\mathrm{EI}_{30}$ and rainfall coefficient showed significant correlation coefficients (Table 2), and thus can be used to determine the average annual rainfall erosivity $\left(\mathrm{EI}_{30}\right)$, in locations with similar climatic characteristics and absence of rainfall data.

TABLE 2. Linear and potential regress equations obtained from pluviograph data.

\begin{tabular}{cllll}
\hline Municipalities & \multicolumn{2}{c}{ Linear Equation } & \multicolumn{2}{c}{ Potential Equation } \\
\hline Dourados & $\mathrm{EI}_{30}=73.464+56.562(\mathrm{Rc})$ & $\mathrm{R}^{2}=0.797$ & $\mathrm{EI}_{30}=80.305(\mathrm{Rc})^{0,8966}$ & $\mathrm{R}^{2}=0.875$ \\
Coxim & $\mathrm{EI}_{30}=247.35+41.036(\mathrm{Rc})$ & $\mathrm{R}^{2}=0.896$ & $\mathrm{EI}_{30}=138.33(\mathrm{Rc})^{0,7431}$ & $\mathrm{R}^{2}=0.914$ \\
Campo Grande & $\mathrm{EI}_{30}=171.40+42.173(\mathrm{Rc})$ & $\mathrm{R}^{2}=0.777$ & $\mathrm{EI}_{30}=139.44(\mathrm{Rc})^{0,6784}$ & $\mathrm{R}^{2}=0.912$ \\
\hline
\end{tabular}

In order to obtain the best coefficients of determination, power equations presented in Table 2 were applied to data from 109 rainfall stations in the State of Mato Grosso do Sul. Thus, by adding up the $\mathrm{EI}_{30}$ data calculated for these stations to those obtained from the precipitation stations, 112 sampling points were computed. Descriptive statistics of the results of calculation of $\mathrm{EI}_{30}$ for these stations are presented in Table 3. 
TABLE 3. Statistic analysis of of the datasets analyzed.

\begin{tabular}{cc}
\hline Statistic & $\mathrm{EI}_{30}$ \\
\hline Size of the sample & 112 \\
Minimum & 5770.1 \\
Maximum & 12953.8 \\
Mean & 9257.7 \\
Median & 9216.8 \\
Kurtosis & 1.03 \\
Asymmetry & 0.18 \\
Coefficient of Variation (\%) & 12.41 \\
P Value & 0.476 \\
\hline
\end{tabular}

The adherence of data to normal distribution ( $p>0.05)$ was verified. This distribution is symmetric, since the asymmetry coefficient is close to zero, implying similar mean and median values.According to (ISAAKS \& SRIVASTAVA, 1989), normality of the data is not a requirement of geostatistics, being convenient only that the distribution does not present very long tails, which could compromise the kriging estimates.

The spherical model was adjusted to the semivariogram for the erosivity data, obtaining values of the nugget effect (Co), semivariance structural (C), baseline (a) and coefficient of determination $\mathrm{R}^{2}$ (Figure 2).

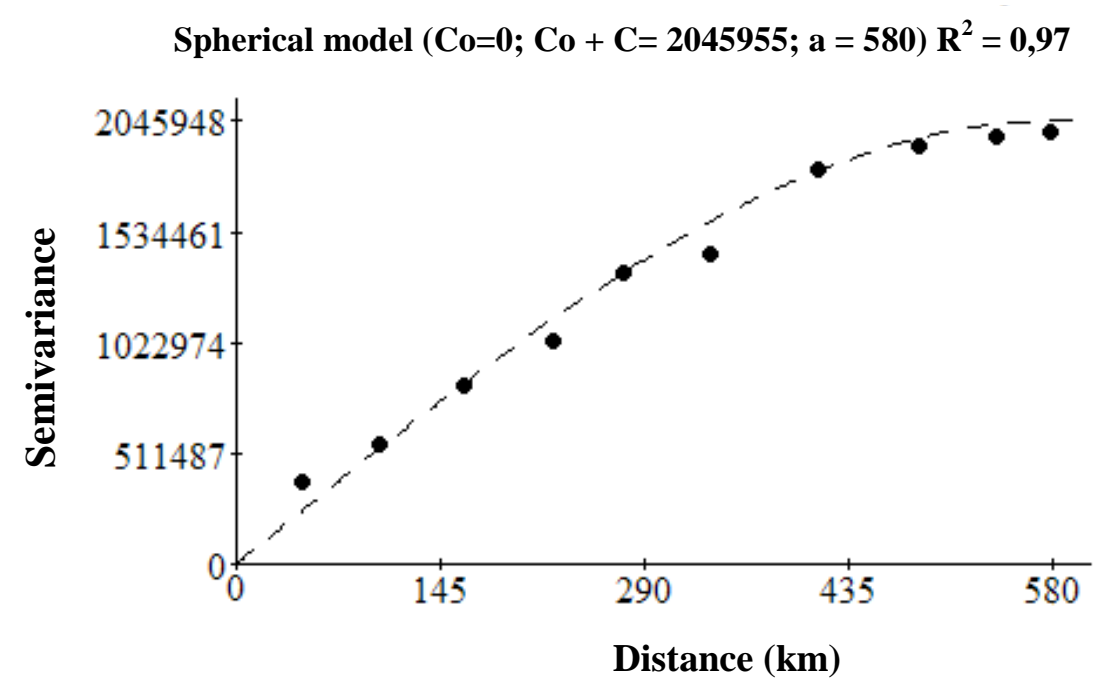

FIGURA 2. Spherical model adjusted to data set.

The nugget effect obtained demonstrates the continuity between adjacent values. The scope of $580 \mathrm{~km}$ indicates that all neighbors located within a circle with this radius can be used to estimate values for any point between them (VIEIRA \& LOMBARDI NETO, 1995). It may be classified the spatial dependence as strong, according to ZIMBACK (2001), thus confirming the existence of spatial dependence of $\mathrm{EI}_{30}$ data.

As the spatial dependence for the $\mathrm{EI}_{30}$ erosivity index, ordinary kriging was used to estimate values at non-sampled points. The values obtained by kriging are ideal for the construction of maps or three-dimensional simulations for the verification and interpretation of spatial variability. The information shown on these maps are useful for understanding the spatial variability of the studied location and to identify areas that need more or less attention (CARVALHO \& ASSAD, 2005). 3.

The average annual erosivity map for the state of Mato Grosso do Sul is represented in Figure 


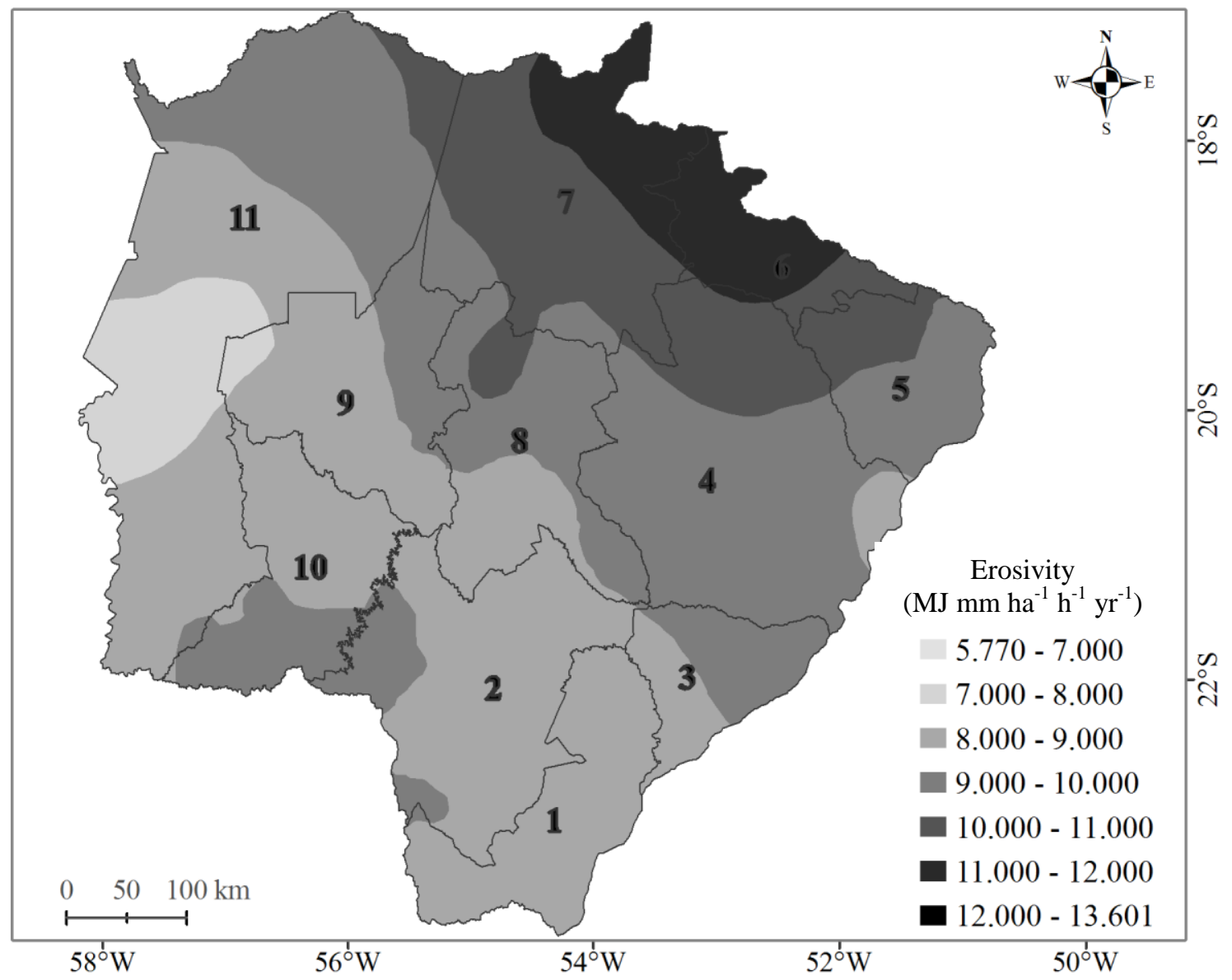

FIGURE 3. Annual erosivity map. Micro-regions: 1. Iguatemi; 2. Dourados; 3. Nova Andradina; 4. Três Lagoas; 5. Paranaíba; 6. Cassilândia; 7. Alto Taquari; 8. Campo Grande; 9. Aquidauna; 10. Bodoquena; 11. Baixo Pantanal.

The average annual erosivity values ranged from 5,770 to $13,601 \mathrm{MJ} \mathrm{mm} \mathrm{ha}^{-1} \mathrm{~h}^{-1} \mathrm{yr}^{-1}$. The average annual erosivity found was 9,318 MJ mm ha ${ }^{-1} \mathrm{~h}^{-1} \mathrm{yr}^{-1}$ and standard deviation was $870 \mathrm{MJ} \mathrm{mm} \mathrm{ha}{ }^{-1} \mathrm{~h}^{-1} \mathrm{yr}^{-1}$. The highest values of erosivity were found in the central and northeast of the State, specifically in the regions of Cassilândia, Alto Taquari, Campo Grande, Três Lagoas and Paranaíba. On the other hand, the lowest values were obtained for the micro-regions of Iguatemi, Dourados, Nova Andradina and Baixo Pantanal. SANTOS et al. (2009) obtained spatial relations of intensity, duration and frequency of precipitation for the state, noticing that the highest levels are found in north-central and the lowest values are in the southeast and southwest of the state.

The coefficient of determination obtained between the annual erosivity and the average annual rainfall was 0.410 (Figure 4), value below that obtained by SILVA (2004) for Brazil. By mapping the erosivity in Brazil, the author concluded that the annual erosivity is highly dependent on the total precipitation, and found a coefficient of determination of 0.975 between these values. MELLO et al. (2007) mapped the erosivity of the State of Minas Gerais and found that the conclusion of SILVA (2004) is not valid for the state of Minas Gerais. The same is observed in Mato Grosso do Sul, i.e., high annual rainfall does not necessarily result in higher $\mathrm{EI}_{30}$ values. 


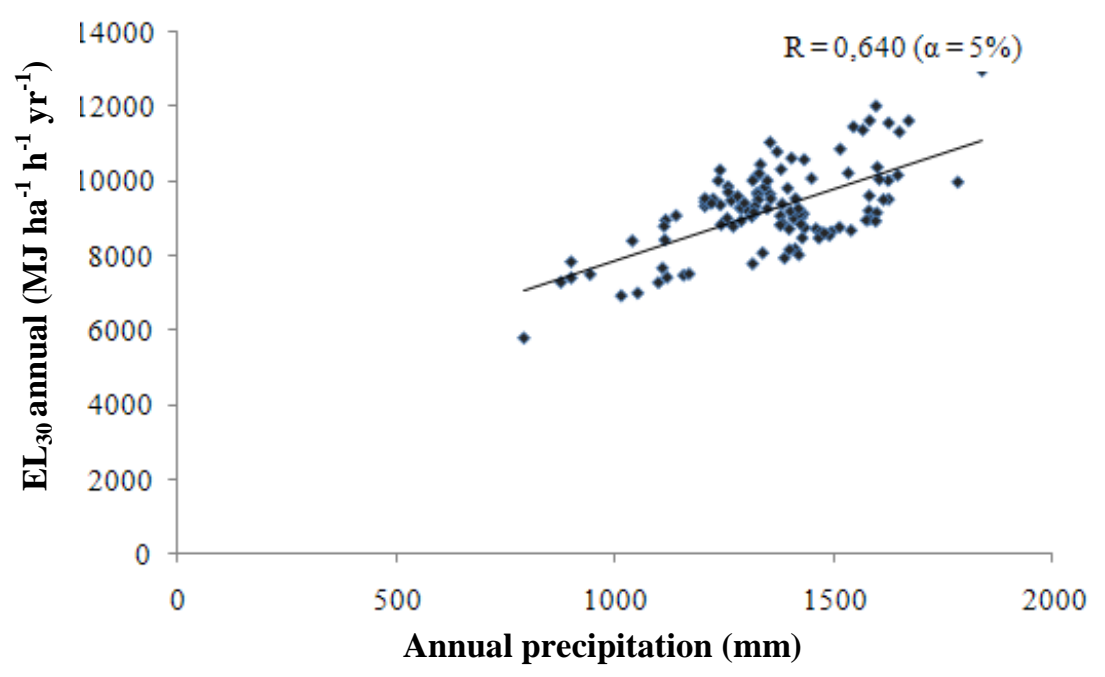

FIGURE 4.Correlation between $\mathrm{EI}_{30}$ and annual precipitation.

The correlation analyses between the annual erosivity and geographical coordinates show that there is no significant correlation between erosivity and latitude. Among the factors correlated, only longitude was not considered significant for $\alpha=5 \%$, i.e., it is not correlated with $\mathrm{EI}_{30}$ (Figures 5 and $6)$.

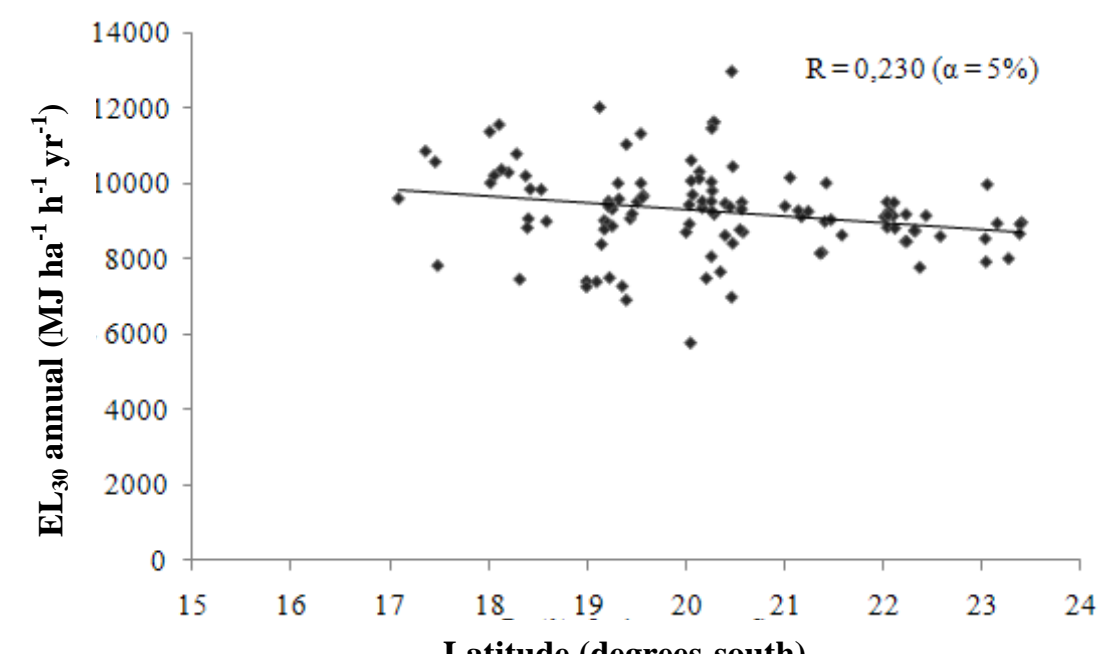

FIGURA 5. Correlation between $\mathrm{EI}_{30}$ and latitude.

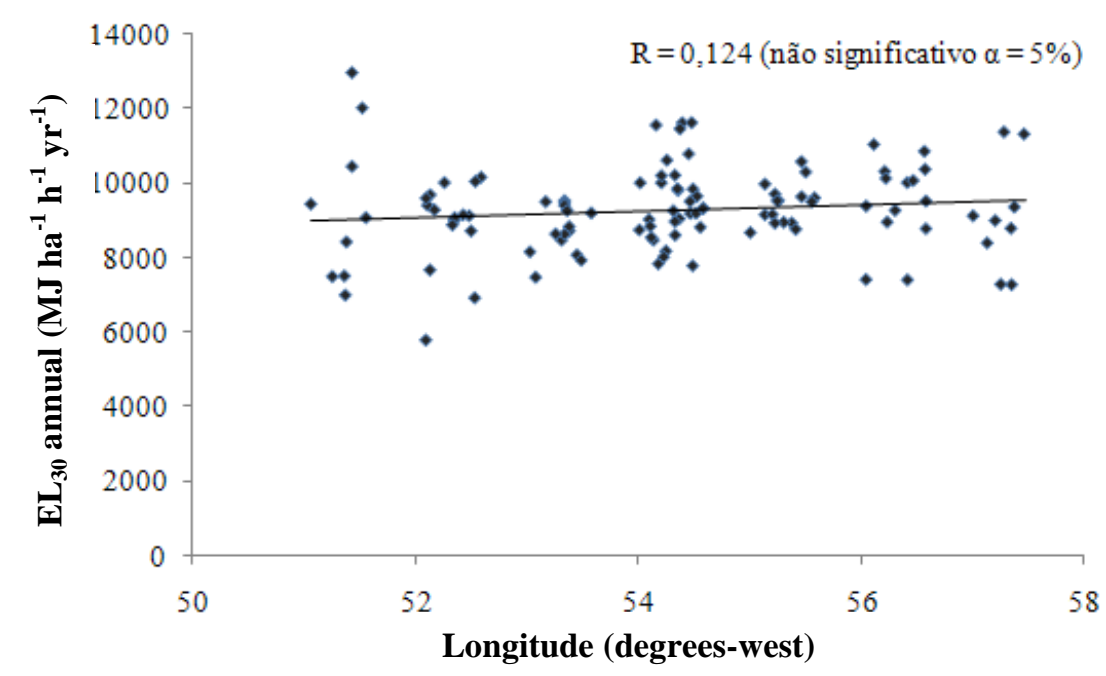

FIGURE 6. Correlation between $\mathrm{EI}_{30}$ and longitude. 
Despite the low $\mathrm{EI}_{30}$ correlation values with geographical coordinates, it can be noticed that the highest values of erosivity were concentrated in the central and northeastern regions of Mato Grosso do Sul (Figure 3). According to NIMER (1989), the Midwest region of Brazil, due to its latitudinal location, is characterized by a transition region between warm climates of low latitudes and mesothermal climates of temperate latitudes. KELLER FILHO et al. (2005) studied the homogeneous rainfall regions in Brazil and found that the south of Mato Grosso do Sul has characteristics similar to rainfall in the north of Paraná, and that the central and northern regions have a rainfall regimen close to São Paulo. Thus, it appears that in the State of Mato Grosso do Sul, the $\mathrm{EI}_{30}$ is associated with concentrations of rainfall at certain times of year, because of its regional climatic characteristics, as well as the dynamics and influence of factors associated with atmospheric circulation.

\section{CONCLUSIONS}

The highest values of erosivity are found in the regions of Cassilândia, Alto Taquari, Campo Grande, Três Lagoas and Paranaíba, whereas the lowest values are observed in the regions of Iguatemi, Dourados, Nova Andradina and Baixo Pantanal.

The annual erosivity in the State of Mato Grosso do Sul has no significant correlation with the longitude and correlates significantly with latitude.

High values of annual precipitation do not necessarily produce higher values of erosivity. In Mato Grosso do Sul, $\mathrm{EI}_{30}$ is associated with concentrations of rainfall at certain times of the year due to regional climate characteristics.

\section{ACKNOWLEDGEMENTS}

The authors express their appreciation to the ConselhoNacional de Desenvolvimento Científico e Tecnológico - CNPq and the Fundação de Apoio ao e Desenvolvimento do Ensino, Ciência e Tecnologia do Estado do Mato Grosso do Sul - FUNDECT for financial aid. The authors would also like to thank the anonymous reviewers for their comments and suggestions that helped improving this study.

\section{REFERENCES}

ANGULO-MARTÍNEZ, M.; BEGUERÍA, S. Estimating rainfall erosivity from daily precipitation records: A comparison among methods using data from the Ebro Basin (NE Spain). Journal of Hydrology, Amsterdam, v.379, n.1-2, p.111-121, 2009.

ANGULO-MARTÍNEZ, M.; LÓPEZ-VICENTE, M.; VICENTE-SERRANO, S.M.; BEGUERÍA, $S$. Mapping rainfall erosivity at a regional scale: a comparison of interpolation methods in the Ebro Basin (NE Spain). Hydrology and Earth System Sciences, Katlenburg-Lindau, v.13, n.10, p.19071920, 2009.

AYRES, M.; AYRES JÚNIOR, M.; AYRES, D.L.; SANTOS, A.S. BioEstat 5.0: Aplicações estatísticas nas áreas das ciências biológicas e médicas. Belém: Sociedade Civil Mamirauá/CNPq, 2007. 380 p.

BERTOL, I.; LEITE, D.; ENGEL, F.L.; COGO, N.P.; GONZÁLEZ, A.P. Erodibilidade de um nitossolo háplico alumínico determinada em condições de campo. Revista Brasileira de Ciência do Solo, Viçosa-MG, v.31, n.3, p.541-549, 2007.

BERTOL, I.; ZOLDAN JUNIOR, W.A.; FABIAN, E.L.; ZAVASCHI, E.; PEGORARO, R.; GONZÁLES, A.P. Efeito de escarificação e da erosividade de chuvas sobre algumas variáveis de valores de erosão hídrica em sistemas de manejo de um nitossolo háplico. Revista Brasileira de Ciência do Solo, Viçosa-MG, v.32, n.2, p.747-757, 2008. 
CAPOLONGO, D.; DIODATO, N.; MANNAERTS, C.M.; PICCARRETA, M.; STROBL, R.O. Analyzing temporal changes in climate erosivity using a simplified rainfall erosivity model in Basilicata (southern Italy). Journal of Hydrology, Amsterdam, v.356, n.1-2, p.119-130, 2008.

CARVALHO, D.F.; MONTEBELLER, C.A.; FRANCO, E.M.; VALCARCEL, R.; BERTOL, I. Padrões de precipitaçãoe índices de erosividade para aschuvas de Seropédica e Nova Friburgo, RJ. Revista Brasileira de Engenharia Agrícola e Ambiental, Campina Grande, v.9, n.1, p.7-14, 2005.

CARVALHO, D.F.; CRUZ, E.S.; PINTO, M.F.; SILVA, L.D.B.; GUERRA, J.G.M. Características da chuva e perdas por erosão sob diferentes práticas de manejo do solo.Revista Brasileira de Engenharia Agrícola e Ambiental, Campina Grande, v.13, n.1, p.3-9, 2009.

CARVALHO, D.F.; MACHADO, R.L.; EVANGELISTA, A.W.P.; KHOURY JÚNIOR, J.K.; SILVA, L.D.B. Distribuição, probabilidade de ocorrência e período de retorno dos índices de erosividade $\mathrm{EI}_{30}$ e KE>25 em Seropédica - RJ. Engenharia Agrícola, Jaboticabal, v.30, n.2, p.244$252,2010$.

CARVALHO, J.R.P.; ASSAD, E.D. Análise espacial da precipitação pluviométrica no Estado de São Paulo: comparação de métodos de interpolação. Engenharia Agrícola, Jaboticabal, v.25, n.2, p.377-384, 2005.

CASSOL, E.A.; ELTZ, F.L.F.; MARTIN, D.; LEMOS, A.M.; LIMA, V.S.; BUENO, A.C. Erosividade, padrões hidrológicos, período de retorno e probabilidade de ocorrência das chuvas em São Borja, RS. Revista Brasileira de Ciência do Solo, Viçosa-MG, v.32, n.3, p.1239-1251, 2008.

CASSOL, E.A.; MARTINS, D.; ELTZ, F.L.F.; LIMA, V.S.; BUENO, A.C. Erosividade e padrões hidrológicos das chuvas de Ijuí (RS) no período de 1963 a 1993.Revista Brasileira de Agrometeorologia, Piracicaba, v.15, n.3, p.220-231, 2007.

ESRI - Environmental Systems ResearchInstitute. ArcGIS Professional GIS for the desktop, version 9.2. Software. 2006 .

GONÇALVES, F.A.; SILVA, D.D.; PRUSKI, F.F.; CARVALHO, D.F.; CRUZ, E.S. Índices e espacialização da erosividade das chuvaspara o Estado do Rio de Janeiro. Revista Brasileira de Engenharia Agrícola e Ambiental, Campina Grande, v.10, n.2, p.269-276, 2006.

GOOVAERTS, P. Using elevation to aid the geostatistical mapping of rainfall erosivity.Catena, Amsterdam, v.34, n.16, p.227-242, 1999.

HOYOS, N.; WAYLEN, P.R.; JARAMILLO, A. Seasonal and spatial patterns of erosivity in a tropical watershed of the Colombian Andes. Journal of Hydrology, Amsterdam, v.314, n.1-4, p.177-191, 2005.

HUDSON, N.W. Soil conservation. New York: Cornell University Press, 1973. 320 p.

ISAAKS, E.H.; SRIVASTAVA, R.M. Applied geoestatistics: introduction to applied geostatistics. Oxford: University Press, 1989. 561 p.

KELLER FILHO, T.; ASSAD, E.D.; LIMA, P.R.S.R. Regiões pluviometricamente homogêneas no Brasil. Pesquisa Agropecuária Brasileira, Brasília, v.40, n.4, p.311-322, 2005.

LOMBARDI NETO, F. Rainfall erosivity - its distribution and relationship with soil loss at Campinas, Brazil. 1977. 53 f. Thesis (M.Sc.) - PurdueUniversity, West Lafayette, 1977.

MACHADO, R.L.; CARVALHO, D.F.; COSTA, J.R.; OLIVEIRA NETO, D.H.; PINTO, M.F. Análise da erosividade das chuvas associada aos padrões de precipitação pluvial na região de Ribeirão das Lajes (RJ). Revista Brasileira de Ciência do Solo, Viçosa-MG, v.32, n.5, p.2113-2123, 2008. 
MELLO, C.R.; SÁ, M.A.C.; CURI, N.; MELLO, J.M.; VIOLA, M.R.; SILVA, A.M. Erosividade mensal e anual da chuva no Estado de Minas Gerais. Pesquisa Agropecuária Brasileira, Brasília, v.42, n.4, p.537-545, 2007.

MONTEBELLER, C.A.; CEDDIA, M.B.; CARVALHO, D.F.; VIEIRA, S.R.; FRANCO, E.M. Variabilidade espacial do potencial erosivo das chuvas no Estado do Rio de Janeiro. Engenharia Agrícola, Jaboticabal, v.27, n.2, p.426-435, 2007.

NIMER, E. Climatologia do Brasil. 2.ed. Rio de Janeiro: Fundação IBGE, 1989. 421 p.

OLIVEIRA, F.P.; SILVA, M.L.N.; CURI, N.; SILVA, M.A.; MELLO, C.R. Potencial erosivo da chuva no vale do Rio Doce, região centro leste do Estado de Minas Gerais - primeira aproximação. Ciência e Agrotecnologia, Lavras, v.33, n.6, p.1569-1577, 2009.

ROBERTSON, G.P. GS+ geostatistics for the environmental sciences: GS+ user's guide. Plainwell: Gamma Design Software, 1998. 152 p.

SANTOS, G.G.; FIGUEIREDO, C.C.; OLIVEIRA, L.F.C.; GRIEBELER, N.P. Intensidadeduração-frequência de chuvaspara o Estado de Mato Grosso do Sul. Revista Brasileira de Engenharia Agrícola e Ambiental, Campina Grande, v.13, p.899-905, 2009. Suplemento.

SHAMSHAD, A.; AZHARI, M.N.; ISA, M.H.; WAN HUSSIN, W.M.A.; PARIDA, B.P. Development of an appropriate procedure for estimation of RUSLE $\mathrm{E}_{\mathrm{I} 30}$ index and preparation of erosivity maps for Pulau Penang in Peninsular Malaysia. Catena, Amsterdam, v.72, n.3, p.423-432, 2008.

SILVA, A.M. Rainfall erosivity map for Brazil. Catena, Amsterdam, v.57, n.3, p.251-259, 2004.

SILVA, A.M.; SILVA, M.L.N.; CURI, N.; AVANZI, J.C.; FERREIRA, M.M. Erosividade da chuva e erodibilidade de cambissolo e latossolo na região de Lavras, Sul de Minas Gerais. Revista Brasileira de Ciência do Solo, Viçosa-MG, v.33, n.6, p.1811-1820, 2009.

VIEIRA, S.R.; LOMBARDI NETO, F. Variabilidade espacial do potencial de erosão das chuvas do Estado de São Paulo. Bragantia, Campinas, v.54, n.2, p.405-412, 1995.

WISCHMEIER W.H. A rainfall erosion index for a universal soil-loss equation. Soil Science Society of America Journal, Madison, v.23, n.3, p.246-249,1959.

WISCHMEIER, W.H.; SMITH, D.D. Predicting rainfall erosion losses. A guide to conservation planning. Washington: USDA Agriculture, 1978. (Handbook, 537).

ZHANG, Y.G.; NEARING, M.A.; ZHANG, X.C.; XIE, Y.; WEI, H. Projected rainfall erosivity changes under climate change from multimodel and multiscenario projections in Northeast China. Journal of Hydrology, Amsterdam, v.384, n.1-2, p.97-106, 2010.

ZIMBACK, C.R.L. Análise espacial de atributos químicos de solos para fins de mapeamento da fertilidade. 2001. 114 f. (Livre-Docência em Levantamento do Solo e Fotopedologia) - Faculdade de Ciências Agronômicas, Universidade Estadual Paulista, Botucatu, 2001. 